\title{
The Effect of Ant Plant on the Increase of CD4 Count in PLHIV in the Papua Province
}

\author{
Arwam Hermanus Markus Zeth ${ }^{1 *}$ (D) Nouvy Helda Warouw ${ }^{2} \mathbb{D}$, Paula Krisanty ${ }^{3} \mathbb{D}$ \\ ${ }^{1}$ Health Polytechnic Ministry of Health, Jayapura, Indonesia; ${ }^{2}$ Jakarta Health Polytechnic II, Ministry of Health Republic of \\ Indonesia, South Jakarta, Indonesia; ${ }^{3}$ Department of Medical-Surgical Nursing, Polytechnic of Health Ministry of Health Jakarta \\ III, Bekasi, Indonesia
}

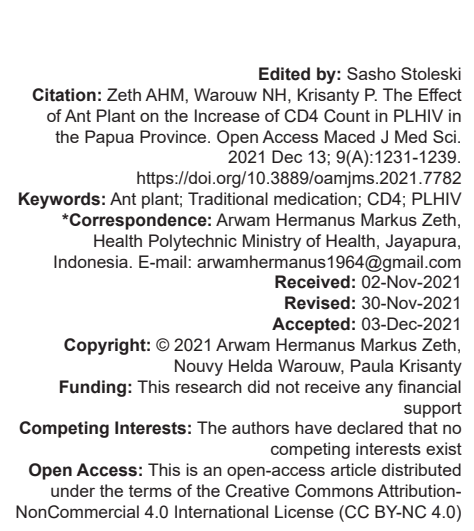

Abstract

BACKGROUND: The ant plant (Myrmecodia pendans), an epiphyte of Hydnophytinae (Rubiaceae), has long been used for traditional medication.

AIM: This research aimed to examine the effect of ant plant on the increase of CD4 count in PLHIV in Papua province and to identify the effect of ant plan supplementation on the increase of CD4 in PLHIV.

METHODS: The research used true experimental design with modified randomized control group pre- and post-tes design. The pre-test was performed by conducting a preliminary count of CD4 in both the intervention and contro groups, to which antiretroviral therapy (ART) has been administered. The intervention group was supplemented with the ant plant on a daily basis, while the control group was given a placebo treatment with tea.

RESULTS: Based on the results, it can be concluded that PLHIV given ant plant supplementation may have a higher increase in their CD4 count after receiving an intervention for 1 month than those who only received ART.

CONCLUSION: Further research is needed to investigate the effect of the ant plant on the viral load in PLHIV.

\section{Introduction}

The ant plant (Myrmecodia pendans) is an epiphyte of Hydnophytinae (Rubiaceae) that has long been in use for traditional medication. Growing on a host plant at the height of $1100-2500 \mathrm{~m}$ above sea level, it has the potential of being natural antioxidant. It is usually attached to other types of plants such as white pasperbark, mountain ru, turmeric, and beech.

The chemical compounds of the flavonoid and tannin groups in the ant plant have been known to have the capability of treating various diseases. Flavonoids function as antibiotic and antivirus to HIV and herpes [1]. They are also used to treat and prevent a number of diseases such as asthma, cataract, diabetes, gout/rheumatoid arthritis, migraine, hemorrhoids, periodontitis, and cancer. They are known to also contain antioxidant compounds, vitamins, minerals, and formic acid. Antioxidants in ants have a role in colony formation and in keeping egg-laying places away from diseases.

HIV is a retrovirus infecting the cells in the human immune system (especially CD4-positive T cells and main macrophages that compose the cell immune system) and destroying or disturbing their functioning. This viral infection causes the immune system to be degraded. The immune system is considered difficient when it is no longer able to run its function in fighting off infections and diseases. People with immunodeficiency become more susceptible to various infections, most of which rarely affect people with no deficiency in their immunity [2].

Indonesia has been categorized as a country at the concentrated epidemic level because it has sacs with prevalence rates above $5 \%$ in several populations [3], necessitating some HIVIAIDS infection mitigation efforts based on the policies that have been established. The purpose of these policies in Indonesia is to keep in control the spread of HIV infection and the quality of life of people living with HIVIAIDS (PLHIV) [4].

The number of HIV and AIDS cases from April 1, 1987, to September 30, 2015, is described as follows: there were 150,285 people with HIV and 55,799 people with AIDS, with a total number of death cases of 9796. Based on gender, the cumulative number of AIDS cases were made up by 30,001 males, 16,149 females, and 9649 people whose gender was unknown. Meanwhile, based on the risk factor, AIDS cases are categorized as follows: 34,305 cases were suffered by heterosexuals, 1366 cases by homo/bisexuals, 8462 cases by injecting drug users (IDUs), 130 cases by 
people who did blood transfusion, 1506 cases by those to whom HIV was perinatally transmitted, and 8536 by people with no known information of HIVIAIDS causes.

The cumulative numbers of HIV and AIDS cases for 33 provinces are described as follows. DKI Jakarta ranked first with 32,782 people with HIV and 7477 people with AIDS. East Java came second with 19,249 people with HIV and 89,760 people with AIDS. Papua was the third with 16,051 people having HIV and 10,184 people suffering from AIDS. All the while, Southeast Sulawesi had 330 people with HIV and 266 people with AIDS, with a prevalence rate of $11.91 \%$.

Papua topped the ranks in the cumulative number of HIVIAIDS cases for the months July-September in $2014(26,235)$, which was comprised of HIV cases at $61.18 \%$ and AIDS cases at $38.8 \%$ [5]. Based on the data of the cumulative number of HIV/ AIDS cases in Papua, $25.37 \%$ of people have died from psychosocial factors and $14.09 \%$ died from unknown causes. A share of $63.77 \%$ of these cases occurred in people in the reproductive age range 15-39 years, suggesting that free sex was to be held responsible for these cases, and $9.39 \%$ of these cases were suffered by pregnant women (Dinkes Papua, 2014).

The aims of antiretroviral therapy (ART) are to suppress the development of HIV RNA replications, to recover and maintain the immunity, and to reduce HIV-related morbidity and mortality [6]. Regardless of the success of ART in reducing the level of severity, in fact, HIV remains a culprit in the reduction of CD4 and increase of viral load as it keeps replicating; it also causes body mass index (BMI) decline.

Meanwhile, ever since the emergence of the epidemic, HIV patients have been experiencing malnutrition (deficient in protein and calory) and micronutrient deficiency disorders such as reductions in antioxidant and Vitamins A, C, and E contents, and they have also been undergoing oxidative stress significantly, leading to HIV mutation and resistance to ART; therefore, a new combination must be prescribed to block the HIV protein as ART has been known to be toxic and have some side effects [7].

HIV-positive people experience protein break-down faster in their body, causing their albumin concentration to be low, but by increasing energy intake, they may improve their protein balance [8]. Nicholas et al. [9] reported in their study that albumin administration can improve immunity against stress from HIV infections. Batterham (2005) has also concluded that if an HIV-infected individual is of a good nutritional status, then their immunity will be better; therefore, they will be slower at entering the AIDS stage, and their life will also be of higher quality.

Studies have found a number of active compounds such as flavonoids, tannins, and polyphenols as antioxidants in the body that are capable of treating a host of diseases. Over 8000 polyphenols have been identified in a variety of plants. Polyphenols typically are conjugated with one or more sugar residues that are attached to the hydroxyl group. Not only are they directly bound to sugars (polysaccharides or monosaccharides), they are also bound in aromatic-carbon bonds. They are also bound to other compounds, such as carboxylate and organic acids, amina, and lipids. Polyphenols can be classified into several groups based on the existing number of phenol rings and the structural elements that bind the ring one another. Among the primary groups are phenolic acids, flavonoids, stilbenes, and lignins.

Flavonoids are red, purple, and blue pigments commonly found in plants. They can reduce the glucose level in the blood with their ability as antioxidants. They are protective against $\beta$ (beta) cell damage as insulin producers, and they can improve the insulin sensitivity. Antioxidants are able to suppress beta cells' apoptosis without changing the proliferation of the pancrease beta cells. Antioxidants are also capable of reactive oxygen species (ROS) reduction. In forming an ROS, oxygen will bind to the free electrons released due to the leak of the electron chain. It is the reaction between oxygen and the free electrons that produces the ROS in the mitochondria. Antioxidants in flavonoids are able to contribute their hydrogen atoms. Flavonoids will be oxidized and bound to free radicals, causing them to be more stable.

The ant plant contains a string of active compounds, particularly flavonoids, which can be used for HIV therapy. Nicholas et al. (2003) reported that administering ant plants that are rich in antioxidants will improve the immunity against the stress from HIV infections through their restraining the ROS formation and their effect on the level of nitric oxide that is produced [9].

In this research, the researchers intended to disseminate information on the importance of the ant plant as a cheap, readily available alternative source of protein as well as information on the fact that it contains important immunonutrients as it has high-quality nutritional values with alternative proteins that are useful in improving the life quality of HIVIAIDS patients.

Papua topped the ranks in the cumulative number of HIVIAIDS cases for the months July-September in $2014(26,235)$, which was comprised of HIV cases at $61.18 \%$ and AIDS cases at $38.8 \%$ [5]. Based on the data of the cumulative number of HIVIAIDS cases in Papua, $25.37 \%$ died from psychosocial factors and $14.09 \%$ died from unknown causes. A share of $63.77 \%$ of these cases occurred in people in the reproductive age range 15-39 years, suggesting that free sex was to be held responsible for these cases, and $9.39 \%$ of these cases were suffered by pregnant women [10].

Recent data from the AIDS Mitigation Commission (KPA) of the Papua Province show that, as of 13 March, there were 25,233 HIV sufferers in Papua, $98 \%$ of whom were infected through sexual intercourse. The highest number of people with HIV/ 
AIDS was recorded to be from the Jayawijaya Regency (5293), followed by the Mimika City (4524). Based on age, the highest number of people with HIVIAIDS was in the age range 25-49 years, with 5333 AIDS cases and 9211 cases [4].

Based on the explanation above, it is presumed that ant plant supplementation is likely to be able to increase the CD4 count in the blood and improve the nutritional status of PLHIV in the Papua province. One of the indicators to extend the cycle between HIV infection and AIDS stages is to maintain the blood CD4 count. If the test shows that CD4 $=34 \%$, then it means $34 \%$ of the lymphocytes are CD4. The normal level will be anywhere between $30 \%$ and $60 \%$. A rate below $14 \%$ shows severe damage to the immune system, indicating AIDS stage in people infected with HIV. A normal CD4 count should be 410 cells $/ \mathrm{mm}^{3}$. If the count is lower than 350 cells $/ \mathrm{mm}^{3}$, or below $14 \%$, then it will be considered an AIDS case [11]. The lower the CD4 count in the blood, the more likely the individuals with HIV are to get an opportunistic infection and to enter the AIDS stage.

This research, thus, aimed to study the effect of the ant plant on the increase of CD4 count in PLHIV in the Papua province and, specifically, to figure out the effect of ant plan supplementation on the increase of CD4 in PLHIV in the Papua province.

\section{Human immunodeficiency virus (HIV) and acquired immune deficiency syndrom (AIDS)}

HIV or Human Immunodeficiency Virus is a retrovirus that infects cells in the human immune system (especially CD4-positive T cells and main macrophages that compose the cell immune system) and destroys and disturbs its functioning. This viral infection will cause a continuous decline to the immune system and ultimately lead to a deficiency in the immunity. The immune system is considered deficient when the body with immunodeficiency becomes more susceptible to a variety of infections, most of which rarely affect people who do not suffer from immunodeficiency [2].

\section{Risk factors}

Among people who are at high risk of being HIVinfected are individuals whose sexual partners are with HIV, IDUs, individuals whose sexual partners are sexual workers, sexual workers' clients as well as the partners of the sexual workers' clients, health workers who are in contact with HIV patients' blood and discharge, recipients of blood transfusion and blood products, and the fetus conceived by individuals with HIV.

\section{HIVIAIDS infection transmission}

HIV may come into the human body especially through blood, semen (seminal fluid) and vaginal discharge, and transmission from mother to child [12]. Retrovirus RNA transmission by blood usually occurs by the following mechanisms: Homosexuality or heterosexuality, getting infected by the blood of people with HIVIAIDS, intravenous drug abuse, blood product transfusion, and transmission from mother to child. HIV transmission from mother to child per se happens during pregnancy, labor, and breastfeeding by mothers with HIVIAIDS.

\section{Etiology}

Acquired Immunodeficiency Syndrome (AIDS) is caused by Human Immunodeficiency Virus (HIV), a cytopathic virus that is classified into the family Retrovirideae, the subfamily Lentivirinae, and the genus Lentivirus. HIV is a ribonucleic acid (RNA) virus with a molecular weight of $9.7 \mathrm{~kb}$ (kilobases). The structure is composed of an outer membrane or envelop that consists of envelope glycoprotein gp120 that is attached to envelope glycoprotein gp4. In the inner part, there is a second layer that is comprised of p17 protein. Then, there is the HIV core that is formed by p24 protein. In the core, there are these important components: 2 RNA strands and reverse transcriptase enzyme. The glycoprotein-formed envelope apparently has a critical role in infections as it has a high degree of affinity for the CD4-specific receptors of the host cells. The RNA molecule is enclosed by bilayer capsid and an enclosing membrain that contains proteins.

An RNA virus in its replication process must make a copy of the Deoxyribonucleic Acid (DNA) and the RNA in the virus. It is the DNA gene that allows the virus to replicate. As with other viruses, HIV can only replicate in the parent cell. Within the viral core there are also some enzymes for making RNA copies that are needed for HIV replication, namely reverse transcriptase and protease. RNA is enclosed by a coneshaped capsule that consists of about 2000 copies of p24 viral proteins. There are two recognized types of HIV: HIV-1, discovered in 1983, and HIV-2, discovered in 1986 in AIDS patients in West Africa. The HIV epidemic on a global scale is mainly caused by HIV-1, while HIV-2 is not too expansive in its scope, encountered only in West Africa and some parts of Europe that are closely related to West Africa [13].

$\mathrm{T}$ lymphocyte count is vital in determining the progressivity of the HIV infection into AIDS. Infected $\mathrm{T}$ cells will no longer function and eventually die. HIV infection is marked by a drastic decrease of the $\mathrm{T}$ cell count in peripheral blood smear [14].

\section{HIV/AIDS infection pathogenesis}

The HIV disease begins with an acute disease that is under the control of some of specific immune response and progresses into a progressive chronic infection in the peripheral lymphoid tissue. The disease's progression can be monitored by counting the viral load 
in the patient's serum and by counting the number of $\mathrm{CD}^{+} \mathrm{T}$ cells in the peripheral blood. Joining the location from which the virus enters the body, CD4 T cells and monocytes in the blood or $\mathrm{CD} 4^{+} \mathrm{T}$ cells and macrophages in the mucose tissue are the first cells to be infected. It is highly likely that dendritic cells have a role in the early spread of HIV in the lymphoid tissue, given the normal function of dendritic cells in capturing antigens in lymph nodes, in which case dendritic cells forward the virus to T cells through contact between cells. In just a couple of days the viral load in the nodes multiplies, causing viremia. At that time the number of HIV particles in the blood is many, and there occurs an accompanying HIV syndrome. Viremia causes the virus to spread throughout the body and infect T cells, monocytes, and macrophages in the peripheral lymphoid tissue. The specific immune system will then attempt to take the infection under control as can be seen in the lowering of the viremia level, although it remains detectable [15].

\section{Clinical manifestation}

Acute infection syndrome is the early stage of HIV infection. The symptoms include fever, weakness, loss of apetite, sore throat (sore when swallowing), coughing, joint pain, diarrhea, swollen lymph nodes, and rash (macula) [16]. The major and minor symptoms in AIDS diagnosis (Table 1) below:

Table 1: Major and minor symptoms in an AIDS diagnosis

\begin{tabular}{ll}
\hline Major symptoms & Minor symptoms \\
\hline Weight loss at $>10 \%$ in a month & Persistent coughing for $>1$ month \\
Chronic diarrhea for $>1$ month & Dermatitis generalisata \\
Prolonged fever for $>1$ month & $\begin{array}{l}\text { Multi-segmental herpes zooster and repeated } \\
\text { lowering of consciousness Kandidiasis } \\
\text { orofaringeal }\end{array}$ \\
& $\begin{array}{l}\text { Chronic herpes simplex } \\
\text { Dementia/HIV encephalopathy }\end{array}$ \\
& $\begin{array}{l}\text { Progresif limfadenopati generalisata } \\
\text { Repeated fungal infection in women's } \\
\text { reproductive organ } \\
\text { Cytomegalovirus retinitis }\end{array}$ \\
\hline Source: [17]. &
\end{tabular}

An AIDS diagnosis can be enforced when one shows to be tested positive for HIV and if there are at least 2 major symptoms and 1 minor symptom.

\section{Clinical symptoms}

According to MFMER (2008), the clinical symptoms of HIVIAIDS are divided into several phases as below: Early phase, advanced phase and final phase are the part of clinical symptoms.

\section{Early phase}

In early infection, there may be no infection symptoms or signs found. However, sometimes, there may occur some symptoms that are alike to flu, such as fever, headache, sore throat, rash, and swollen lymph nodes. Although they show no infection symptoms, HIVIAIDS patients at this stage may transmit the virus to others.

\section{Advanced phase}

Patients will remain to show no symptoms for 8-9 years or more. However, with the progression of the virus and the destruction of the immune cells, HIVIAIDS patients will start to display some chronic symptoms, such as swollen lymph nodes (often being typical symptom), diarrhea, weight loss, fever, coughing, and shortness of breath.

\section{Final phase}

At this stage of HIV infection, which occurs around 10 years or more after a patient first getting infected, more severe symptoms start to show up until this infection ends up in the stage called AIDS. At the AIDS stage, the immune system will drop significantly, allowing the chance of the patient to get some opportunistic infections. During this phase, the following symptoms may also occur: night sweat, shivering, high temperature above $38^{\circ} \mathrm{C}$ that persists for several weeks, chronic diarrhea, dry coughing, shortness of breath, and white spots around the tongue and mouth.

\section{Ant plant}

The ant plant ( $M$. pendans) is an epiphyte from Hydnophytinae (Rubiaceae) and has long been known and used as a traditional medicine, which potentially has the ability as a natural antioxidant. It grows on an $8 \mathrm{~m}$ tall host tree at the height of 1100-2500 $\mathrm{m}$ above sea level, and it has been well-known among the local people of Southeast Asia. This tuberous plant that is cavernous at the stem usually grows attached on some types of plants, such as white paperbark, mountain ru, turmeric, and beech. It is classified into the kingdom Plantae, the sub-kingdom Tracheobionta, the superdivision Spermatophyta, the division Magnoliophyta, the class Magnoliopsida, the sub-class Asteridae, the order Rubiales, the family Rubiaceae, the genus Myrmecodia, and the species M. pendans (Wikipedia, 2011).

The inner part of the stem of the ant plant is hollow and segmented resembling a labyrinth in which an ant colony usually lives. The ant colony that lives in the hollow stem of $M$. pendans is of the species Iridomyrmex cordatus. The uniqueness of the ant plant lies in its interaction with the ants that are nesting in the tubers that exist in the tunnels within. The temperature stability within makes the ant colony like it to live for a long time in the plant. After a long while, there naturally occurs a chemical reaction between the compounds produced by the ants and the substances contained in the fruits of the ant plant. The roots of the ant plant do not function to absorb nutrients; they only bind to the host tree. The ant plant contains flavonoids, tannins, and tocopherol antioxidants (Vitamin E), as well as some important minerals for the body, such as calcium, 
natrium, potassium, zinc, iron, phosphorus, and magnesium. Flavonoids are natural antioxidants that are able to reduce hydroxyl, superoxide, and peroxyl radicals [18].

The chemical compounds of the flavonoid and tannin groups contained in the ant plant are known to be able to treat various diseases. Flavonoids function as antibiotic and antivirus for HIV and herpes [1]. They are also used to treat and prevent some diseases such as asthma, cataract, diabetes, gout/rheumatoid arthritis, migraine, hemorrhoids, periodontitis, and cancer. The ant plant is reckoned to contain antioxidant compounds, vitamins, minerals, and formic acids. The antioxidants in the ants have a role in colony formation and keeping egg-laying places away from any diseases.

The ant plant is usually used as medicine at its hypocotyl (caudex) part [1]. To use it as medicine, the hypocotyl part of the ant plant that has been dried is submerged in water and put to boiling [19]. From a chemical screening, it was figured out that the ant plant contains active compounds of the flavonoid group.

\section{Substances contained in the ant plant}

According to Dr. M. Ahkan Subroto, Chief Research Expert at the Indonesian Institute of Sciences (LIPI), the active compounds contained in the ant plant (i.e., flavonoids, tannins, and polyphenols) act as antioxidants in the body. In the ant plant, other useful contents are also there to be found, such as tocopherol, magnesium, calcium, iron, phosphorus, sodium, and zinc.

\begin{tabular}{|c|c|c|c|}
\hline No & Parameter & Unit & Value \\
\hline 01 & Energy & Kkal/100 g & 350.52 \\
\hline 02 & Water content & $g / 100 \mathrm{~g}$ & 4.54 \\
\hline 03 & Ash content & $\mathrm{g} / 100 \mathrm{~g}$ & 11.13 \\
\hline 04 & Fat content & $g / 100 \mathrm{~g}$ & 2.64 \\
\hline 05 & Protein content & $\mathrm{g} / 100 \mathrm{~g}$ & 2.75 \\
\hline 06 & Carbohydrate content & $\mathrm{g} / 100 \mathrm{~g}$ & 78.94 \\
\hline 07 & Tocopherol & $\mathrm{mg} / 100 \mathrm{~g}$ & 31.34 \\
\hline 08 & Total phenol & $\mathrm{g} / 100 \mathrm{~g}$ & 0.25 \\
\hline 09 & Calcium (Ca) & $\mathrm{g} / 100 \mathrm{~g}$ & 0.37 \\
\hline 10 & Sodium ( $\mathrm{Na}$ ) & $\mathrm{mg} / 100 \mathrm{~g}$ & 68.58 \\
\hline 11 & Potassium (K) & $\mathrm{g} / 100 \mathrm{~g}$ & 3.61 \\
\hline 12 & Zinc (Zn) & $\mathrm{mg} / 100 \mathrm{~g}$ & 1.36 \\
\hline 13 & Iron $(\mathrm{Fe})$ & $\mathrm{mg} / 100 \mathrm{~g}$ & 29.24 \\
\hline 14 & Phosphorus (P) & $\mathrm{g} / 100 \mathrm{~g}$ & 0.99 \\
\hline 15 & Magnesium (Mg) & $\mathrm{g} / 100 \mathrm{~g}$ & 1.50 \\
\hline
\end{tabular}

Flavonoids in the human body function as antioxidants, hence excellent for cancer prevention. Flavonoids are useful in protecting the cellular structure, increasing the effectiveness of Vitamin C, acting as anti-inflammation agents, preventing osteoporosis, and acting as antibiotics. They are natural compounds from the phenolic compound group largely found in plant pigments. Currently, there are over 6000 diverse compounds belonging to the flavonoid group. They are a vital part in human diet thanks for their benefits for health.

In many cases, flavonoids may have a direct role as antibiotics by disturbing the functions of microorganisms such as bacteria and viruses. Their function as antiviruses has been vastly published, including in their ability against HIVIAIDS and the herpes virus. They have also been reported to have a role in preventing and treating a number of other diseases, such as asthma, cataract, diabetes, gout/rheumatoid arthritis, migraine, hemorrhoids, and periodintitis (inflammation in the connective tissue at the base of the tooth roots). Other recent studies have also revealed other functions of flavonoids: they are useful not only for the prevention of cancer, but also for the treatment thereof. Many of the work mechanisms of flavonoids have been unveiled, for example, carcinogen inactivation, anti-proliferation, inhibition of the cell cycle, apoptosis induction, differentiation, inhibition of angiogenesis, the reverse of multi-drug resistance, or a combination of the aforementioned mechanisms. Empirically speaking, the ability of the ant plant in the medication of various types of cancers or tumors, TBC, and gout/rheumatoid arthritis is strongly assumed to have an association with the flavonoids contained within the ant plant.

Tannins, the next compounds in the ant plant, are astringents that bind and cause to deposit excessive proteins in the body. In the field of medicines, tannins are used to treat diarrhea, hemostasis (causing bleeding to a stop), and hemorrhoids. Therefore, the empirical ability of the ant plant in treatment, as in the treatment of hemorrhoids and nosebleed, is strongly assumed to be related to these substances.

Besides, there are also polyphenols, which are phenolic acids and flavonoids. They are commonly found in fruits, vegetables, and seeds. These bitter substances are able to bind and cause to deposit proteins. On average, humans can consume polyphenols of up to $23 \mathrm{mg} /$ day. Polyphenols are capable of being anti-microbial agents and lowering down the blood glucose level. Phenolic acids are a class of antioxidants or compounds that eliminate free radicals. These unstable molecules are produced from normal metabolism that blocks the blood veins and makes a change to DNA, causing cancers and some other diseases.

This plant is also rich in the antioxidant tocopherol (Vitamin E) (at around 313 ppm). Antioxidant analysis of the crude extract of the ant plant using the 1,1-diphenyl-2-picrylhydrazyl method shows that the extract has a moderate antioxidant activity with $\mathrm{IC}_{50}$ of $48.6 \mathrm{ppm}$. Meanwhile, alpha-tocopherol shows a strong antixoxidant activity with $\mathrm{IC}_{50}$ of $5.1 \mathrm{ppm}$. $\mathrm{IC}_{50}$ refers to the antioxidant concentration that is able to restrain or inhibit $50 \%$ free radicals. The smaller the $\mathrm{IC}_{50}$ of an antioxidant the stronger the antioxidant activity.

Alpha-tocopherol at the concentration of $12 \mathrm{ppm}$ has been able to restrain $96 \%$ free radicals, and this percentage of inhibition remains constant at concentrations above $12 \mathrm{ppm}$. This shows that, even at low concentrations, alpha-tocopherol has demonstrated a restraining activity. 
In addition, the ant plant contains a number of important minerals for the body, such as calcium, sodium, potassium, zinc, iron, phosphorus, and magnesium.

Magnesium has some roles in the bones, liver, and muscles, intracellular water transfer, acidbase balance, and neuromuscular activity. Calcium functions in the work of the heart, nerve impulse, and blood clotting. Iron, meanwhile, functions in hemoglobin formation, oxygen transport, and enzyme activation.

The next mineral, phosphorus, absorbs calcium and produces energy, whereas sodium has a role in the electrolyte balance, body fluid volume, nerve impulse, and the acid-base balance.

Sodium plays a role in the electrolyte balance, body fluid volume, and nerve impulse. Potassium functions in the heart rhythm, nerve impulse, and the acid-base balance. Lastly, zinc has a function in protein synthesis, sexual function, insulin storage, carbohydrate metabolism, and wound healing.

These minerals' functions can explain the ant plant's several other usages, as in helping deal with various heart diseases/disorders, regularizing menstruation and treating leukorrhea, improving blood circulation, treating migraine (headache on one side of the head), dealing with kidney and prostate disorders, recovering body fitness and stamina, and recovering sexual desire.

Analysis of the inhibition of xanthine oxidase activity by ant plant extract has also shown that the extract of this plant has the ability to inhibit the activity of xanthine oxidase at a level with allopurinol, a commercial drug used for the treatment of gout. It is assumed that this activity of xanthine oxidase is inhibited by compounds of the flavonoid group. This function has provided a ground to support the ant plant's empirically proven efficacy in rheumatoid arthritis treatment.

In one of his studies, Dr. M. Ahkan Subroto has likened the ant plant's ability to inhibit xanthine oxidase activity to that of allopurinol. However, while allopurinol may increase the creatine level in the body and thus risk damage to the kidney, the ant plant can conversely improve the kidney function while at the same time lower down the uric acid level in the body.

"With such empirical evidence, the ant plant is (said to be) a new source for medication. (It contains) many new compounds of unknown (type) with high activity." Dr. Muhammad Ahkam Subat, Ant Plant Researcher.

This plant has still a lot of other possible, and still unknown, active compounds that may explain its exceptional efficacy in helping with the recovery of a good many people from various diseases (Source: the book Gempur Penyakit dengan Sarang Semut by Dr. Ir. Ahkam). The conceptual framework can be seen in Figure 1 below:

\section{Conceptual Framework [Figure 1]}

Independent Variable Dependent Variable

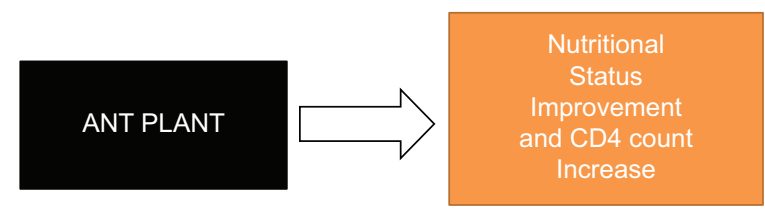

Figure 1: Conceptual framework

\section{Research variables}

1. Independent variable: Ant plant

2. Dependent variable: CD4 count Increase, BMI Improvement.

\section{Research hypotheses}

Based on the theoretical and empirical foundations, the following hypotheses on the relationship between PLHIV and ART are proposed:

1. The CD4 count of PLHIV to whom ant plant supplementation is administered is better than the CD4 count of PLHIV taking only ART (Placebo)

2. The BMI of PLHIV to whom ant plant supplementation is administered is better than the BMI of PLHIV taking only ART (Placebo).

\section{Methodology}

This research used the true experimental method with the modified randomized control group pre- and post-test design. In this research, pre-test was performed by conducting a preliminary count of CD4 count in both the intervention and control groups, to which ART has been administered. The intervention group was supplemented with the ant plant on a daily basis (every morning, noon, and afternoon), while the control group was given a placebo treatment with tea (every morning, noon, and afternoon).

This research was conducted at Abepura. This research was done in three stages:

1. Research preparation stage: to prepare the proposal, to present the proposal in a seminar, and to revise the proposal

2. Research conduct stage: consisting of the early, mid-, and final phases of the research

3. Report writing stage: covering the research findings, ended with a research findings seminar. The research took 1 month to complete.

The population was all the PLHIV visiting the VCT clinic to receive ART. The sample as the research subjects was derived by total sampling. There were 10 PLHIV, all of whom were recruited as the research 
sample. The sample was divided into two groups, each consisting of 5 PLHIV. The first group, named P1, was to receive ART and ant plant supplementation, while the second group, named $P 2$, was to receive ART and a placebo treatment. The inclusion criteria were as follows: (1) ART-taking PLHIV and (2) willing to participate in the research as marked by their "informed consent". Meanwhile, the exclusion criteria were as follows: (1) not signing the informed consent and (2) DO (when the patients in this research did not follow through the research procedures).

\section{Data collection and analysis techniques}

The primary data collected in this research were obtained from PLHIV's CD4 counting before and after receiving the ant plant supplement. The data analysis was performed.

1. To compare between two groups using independent samples t-test if the data were normally distributed or Mann-Whitney test if the data were not normally distributed, and

2. To compare between measurements (pre- and post-test) using paired samples t-test if the data were normally distributed or Wilcoxon test if the data were not normally distributed.

\section{Results and Discussion}

\section{Sampling and laboratory examination locations}

The research material used was a product under the brand Sarang Semut Super. Ten respondents were assigned into two groups. One of the groups was an intervention group with five PLHIV who had taken ART and received supplementation with Sarang Semut Super at three bottles per day. Clinical examination of CD4 through pre- and post-test at the laboratory of Puskesmas Waena was then carried out. The other group was a control group with 5 PLHIV, who continued their ART regiment. Clinical examination of CD4 through pre- and post-test was also carried out at the same health facility. BMI was measured during pre- and post-test in both groups.

\section{The characteristics of the intervention and control groups}

Ten respondents participated in this research. The characteristics distribution of the respondents of this research is provided in Table 2 below:
Table 2: Distribution of the respondents' characteristics by treatment

\begin{tabular}{|c|c|c|c|c|c|c|}
\hline \multirow[t]{3}{*}{ Respondents' characteristics } & \multicolumn{4}{|c|}{ Groups } & \multirow{2}{*}{\multicolumn{2}{|c|}{ Total }} \\
\hline & \multicolumn{2}{|c|}{$\begin{array}{l}\text { Ant plant } \\
\text { treatment }\end{array}$} & \multicolumn{2}{|c|}{$\begin{array}{l}\text { Placebo } \\
\text { control }\end{array}$} & & \\
\hline & $\mathrm{n}$ & $\%$ & $\mathrm{n}$ & $\%$ & $\mathrm{n}$ & $\%$ \\
\hline \multicolumn{7}{|l|}{ Age } \\
\hline $25-27$ уо & 2 & 40 & 3 & 6040 & 5 & 50.0 \\
\hline $27-29$ yо & 3 & 60.0 & 2 & 40.0 & 5 & 50.0 \\
\hline \multicolumn{7}{|l|}{ Tribe } \\
\hline Fakfak & 2 & 40.0 & 3 & 60.0 & 5 & 50.0 \\
\hline Wamena & 2 & 40.0 & 1 & 20.0 & 3 & 30.0 \\
\hline Ambon & 1 & 20.0 & 1 & 20.0 & 2 & 20.0 \\
\hline \multicolumn{7}{|l|}{ Education } \\
\hline Low & 4 & 80.0 & 3 & 60.0 & 7 & 70.0 \\
\hline High & 1 & 20.0 & 2 & 40.0 & 3 & 30.0 \\
\hline \multicolumn{7}{|l|}{ Marital status } \\
\hline Married & 1 & 80.0 & 1 & 20.0 & 5 & 50.0 \\
\hline Widowed & 4 & 20.0 & 4 & 80.0 & 5 & 50.0 \\
\hline
\end{tabular}

The results of the observation show the following. Respondents aged 25-27 years old made up $40.0 \%$ of the intervention group ( 2 individuals) and $60.0 \%$ of the control group (3 individuals). In terms of tribal affiliation, 2 respondents (40\%) in the intervention group was of the Fakfak tribe, and another 2 (40\%) were of Wamena. In the control group, 3 respondents were of the Fakfak tribe $(60 \%)$.

Based on education level, the respondents of both the intervention and control groups were predominantly of low educational background, each with $4(80.0 \%)$ and 3 respondents $(60.0 \%)$ being low-educated. As for marital status, both the intervention and control groups had 4 respondents being of widowed status $(80.0 \%)$.

\section{Research results on CD4 CD4}

The results of the biochemical examination for the CD4 counts of the research subjects are presented at the Table 4.

Table 4: Average CD4 counts prior to and after intervention in the intervention and control groups

\begin{tabular}{|c|c|c|c|c|}
\hline \multirow{3}{*}{ Groups } & \multicolumn{2}{|c|}{ CD4 measurement } & \multirow{3}{*}{$\mathrm{p}$-value } & \multirow{3}{*}{ Difference } \\
\hline & Before & After & & \\
\hline & Mean \pm SD & Mean \pm SD & & \\
\hline Intervention & $222.60 \pm 197.57$ & $234.60 \pm 191.25$ & $0.025^{* \star}$ & $12.00 \pm 7.65$ \\
\hline Control & $475.60 \pm 110.90$ & $472.40 \pm 112.57$ & $0.306^{* *}$ & $-3.2 \pm 6.10$ \\
\hline
\end{tabular}

The analysis on the intervention group shows a significant increase in CD4 count $(p=0.025<0.05)$ from 222 before intervention to 234 after intervention, with a difference of 12 points. As for the analysis on the control group, no significant difference before (475) and after (472) the intervention ( $p=0.306>0.05)$, with a difference of -3.2 points.

The data above suggest that there was an increase in CD4 count in the intervention group to whom ant plant intervention was applied for 1 month, but there was no increase in CD4 count in the control group after receiving the placebo treatment for the same length of time. 


\section{Discussion}

This research sought to see the nutritional status and CD4 count increase in PLHIV who were given ART and ant plant supplementation in comparison to the CD4 count in PLHIV who were treated with placebo supplementation.

The effect of ant plant supplement on the increase of CD4 count.

CD4 test is a standard test to assess advanced prognosis into the AIDS stage or death, to form differential diagnoses in patients with symptoms, to make therapeutic decisions on ART, and to perform prophylaxis for opportunistic pathogens. CD4 count is the most reliable indicator for prognosis.

The results of the first measurement on the CD4 counts of the research subjects show that individuals had CD4 counts below 350 and individuals had CD4 counts above 500 .

Meanwhile, the paired samples t-test results show that there was a significant increase of CD4 count after the intervention in the intervention group ( $p=0.015<0.05$ ) as well as in the control group $(p=0.001)$. The ANOVA results indicate that both the placebo treatment on the control group and the ant plant treatment on the intervention group had a significant effect on the increase of the PLHIV's CD4 count.

Glutamic acid is able to increase $\mathrm{CD}^{+}$ cytokines. According to Green et al. (2000), CD4 cytokines are vital in activating alveolar macrophages and stimulating T helper-1 to produce IFN-1. CD4 is the basis for the formation of specific immune response to infections, especially intracellular pathogens. CD4 count is a significant predictor of disease progression as well as survival. The guides of the US Department of Health and Human Services and WHO recommend ART application based on CD4 over other immunological markers. Progressive decrease of CD4 count is related to disease progression and increased likelihood of opportunistic infections, wasting, and death. A study shows that HIVIAIDS patients with CD4 counts $<200$ cells $/ \mathrm{mm}^{3}$ are 591 times at higher risk of developing anemia $(p=$ 0.001 ) than patients with CD4 counts $>200$ cells $/ \mathrm{mm}^{3}$.

The absolute CD4 count in adolescents and adults ranges between 500 cells $/ \mathrm{mm}^{3}$ of blood and 1500 cells $/ \mathrm{mm}^{3}$ of blood. In general, the CD4 T lymphocyte count would decline progressively with the progression of the disease. It is possible that the disease progression into the AIDS stage without any application of ART would increase with the increase of the degree of immunodeficiency (decrease of CD4 count). Opportunistic infections and other HIV-related conditions would increase significantly when the CD4 count is $<200$ cells $/ \mathrm{mm}^{3}$. The response to ART is influenced by the immunological stage at which the therapy is started. Patients who start ART at CD4 counts $<50$ cells $/ \mathrm{mm}^{3}$ are exposed to a greater risk of death (Langford et al., 2007).

The regulatory role of branched-chain amino acids (BCAA) in the ant plant is able to help with protein metabolism to control wasting in HIV infection. This process particularly applies to muscular proteins in biological and psychological stress environments related to intracellular BCAA decrease that is induced by stimulation of amino acid oxidation. In later years, it becomes known that BCAA has a positive effect in boosting protein synthesis and in preventing protein degradation through the anticatabolic role of BCAA.

The chemical compounds of the flavonoid and tannin groups contained in the ant plant are recognized to have the ability to treat a variety of diseases. Flavonoids function as antibiotic and antivirus for HIV and herpes (Soeksmanto et al., 2010). They are also used to treat and prevent various diseases, such as asthma, cataract, diabetes, gout/rheumatoid arthritis, migraine, hemorrhoids, periodontitis, and cancer. The ant plant is also known to contain antioxidant compounds, vitamins, minerals, and formic acids. The antioxidants in ants have a role in colony formation and in keeping egg-laying places away form diseases.

Flavonoids in the human body function as antioxidants, hence excellent for cancer prevention. Flavonoids are useful in protecting the cellular structure, increasing the effectiveness of Vitamin C, acting as anti-inflammation agents, preventing osteoporosis, and acting as antibiotics. They are natural compounds from the phenolic compound group largely found in plant pigments. Currently, there are over 6000 diverse compounds belonging to the flavonoid group. They are a vital part in human diet thanks for their benefits for health.

In many cases, flavonoids may have a direct role as antibiotics by disturbing the functions of microorganisms such as bacteria and viruses. Their function as antiviruses has been vastly published, including in their ability against HIVIAIDS and the herpes virus. They have also been reported to have a role in preventing and treating a number of other diseases, such as asthma, cataract, diabetes, gout/ rheumatoid arthritis, migraine, hemorrhoids, and periodintis (inflammation in the connective tissue at the base of the tooth roots). Other recent studies have also revealed other functions of flavonoids: they are useful not only foreol the prevention of cancer, but also for the treatment thereof. Many of the work mechanisms of flavonoids have been unveiled, for example, carcinogen inactivation, anti-proliferation, inhibition of the cell cycle, apoptosis induction, differentiation, inhibition of angiogenesis, the reverse of multi-drug resistance, or a combination of the aforementioned mechanisms. Empirically speaking, the ability of the ant plant in the medication of various types of cancers or tumors, TBC, and gout/rheumatoid arthritis is strongly assumed to have an association with the flavonoids contained within the ant plant. 
Tocopherol (Vitamin E) exists at around $313 \mathrm{ppm}$. Antioxidant analysis of the crude extract of the ant plant shows that the extract has a moderate antioxidant activity with $\mathrm{IC}_{50}$ of $48.6 \mathrm{ppm}$. Meanwhile, alpha-tocopherol shows a strong antixoxidant activity with $I_{50}$ of $5.1 \mathrm{ppm}$. $\mathrm{IC}_{50}$ refers to the antioxidant concentration that is able to restrain or inhibit $50 \%$ free radicals. The smaller the $\mathrm{IC}_{50}$ of an antioxidant the stronger the antioxidant activity.

Alpha-tocopherol at the concentration of 12 ppm has been able to restrain $96 \%$ free radicals, and this percentage of inhibition remains constant at concentrations above $12 \mathrm{ppm}$. This shows that, even at low concentrations, alpha-tocopherol has demonstrated a restraining activity.

Magnesium has some roles in the bones, liver, and muscles, intracellular water transfer, acid-base balance, and neuromuscular activity. These mineral functions can explain the ant plant's several other usages, as in helping deal with various heart diseases/ disorders, regularizing menstruation and treating leucorrhea, improving blood circulation, treating migraine (headache on one side of the head), dealing with kidney and prostate disorders, recovering body fitness and stamina, and recovering sexual desire.

The substances contained in the ant plant as mentioned above can improve the life quality of PLHIV. Therefore, this plant has an effect on the improvement of nutritional status and CD4 count in PLHIV.

\section{Conclusion}

Based on the research results, it can be concluded that PLHIV who are given ant plant supplementation may have a higher increase in their CD4 count after receiving an intervention for 1 month than those who only take ART. Further research is needed to investigate the effect of the ant plant on the viral load in PLHIV.

\section{References}

1. Soeksmanto A, Subroto MA, Wijaya H, Simanjunta P. Anticancer activity test for extracts of sarang semut plant (Myrmecodya pendens) to HeLa and MCM-B2 cells. Pak J Biol Sci. 2010;13(3):148-51. https://doi.org/10.3923/pjbs.2010.148.151

\section{PMid:20437705}

2. Sepkowitz KA. AIDS the first 20 years. $N$ Engl J Med. 2001;344(23):1764-72. https://doi.org/10.1056/ NEJM200106073442306

PMid:11396444

3. Badan Komisi Penanggulangan Aids Papua. Laporan Kasus HIV dan AIDS; 2014

4. KPA Papua. Laporan Tahunan Perkembangan HIV di Papua. KPA Papua; 2016.

5. Kemenkes RI. Statistik Kasus HIVIAIDS di Indonesia. Kemenkes $\mathrm{RI} ; 2014$.

6. Woolfolk-Hoy A, Hoy WK, Davis HA. Teachers' self-efficacy beliefs. In: Wentzel KR, Wigfield A, editors. Handbook of Motivation at School. Routledge: United Kingdom; 2009. p. 627-53.

7. Suryani, Criestie NE. Hubungan antara Pemahaman tentang HIV/ AIDS dengan Kontrol Diri pada Mantan Wanita Tuna Susila; 2011.

8. Jahoor F, Abramson S, Heird WC. The protein metabolic response to HIV infection in young children. Am J Clin Nutr. 2003;78(1):182-9. https://doi.org/10.1093/ajcn/78.1.182 PMid:12816789

9. Paton NI, Ng YM, Chee CB, Persaud C, Jackson AA. Effects of tuberculosis and HIV infection on whole-body protein metabolism during feeding, measured by the $[15 \mathrm{~N}]$ glycine method. Am J Clin Nutr. 2003;78(2):319-25. https://doi.org/10.1093/ajcn/78.2.319 PMid: 12885716

10. Jourdain G, Mary JY, Le Coeur S, Ngo-Giang-Huong N, Yuthavisuthi $\mathrm{P}$, Limtrakul $\mathrm{A}$, et al. Risk factors for in utero or intrapartum mother-to-child transmission of human immunodeficiency virus Type 1 in Thailand. J Infect Dis. 2007;196(11):1629-36. https://doi.org/10.1086/522009 PMid:18008246

11. Niu F, Lewuk SN, Amal F. The relationship between knowledge and attitude of pregnant mother on HIVIAIDS in doing VCT in Puskesmas Abepura. J Keperawatan Trop Papua. 2019;2(2):115-9.

12. Arif M. Kapita Selekta Kedokteran. Jakarta: FKUI; 2001.

13. Barré-Sinoussi F, Chermann JC, Rey F, Nugeyre MT, Chamaret S, Gruest J, et al. Isolation of a T-lymphotropic retrovirus from a patient at risk for acquired immune deficiency syndrome (AIDS). Science. 1983;220(4599):868-71. https://doi. org/10.1126/science.6189183 PMid:6189183

14. Baratawidjaja KG, Rengganis I. Imunologi Dasar. Bala Pennerbit FK UI; 2010.

15. Nasrouddin. Pendekatan Biologi Molekuler, Klinis dan Sosial. FK Unair: Tim Medik AIDS RSU Dr. Soetomo; 2007.

16. Kemenkes RI. Laporan Pemodelan Matematika Epidemi HIV di Indonesia. Kemenkes RI; 2012.

17. Kemenkes RI. Pedoman Nasional Pencegahan Penularan HIV Dari ibu ke Anak (PPA). Kemenkes Rl; 2012.

18. Nurjaman A. Enhancing the mathematic communication ability of junior high school student through cooperative learning model of think pair share (TPS). Didaktik. 2015;9(1):1-9.

19. Hertiani T. New hope on drug leads development from deep ocean: halogenated alkaloids of agelas sponges. Indones J Pharm. 2014;25(4):199. http://doi.org/10.14499/ indonesianjpharm25iss4pp199 